\title{
UJI EFEK ANTIBAKTERI REBUSAN DAUN SIRSAK (Annona muricata L.) TERHADAP PERTUMBUHAN BAKTERI Staphylococcus aureus
}

\author{
Jafril Rezi, Rini Andarwati, Zulfa Ismaniar Fauzi \\ jurusan Farmasi Poltekkes Medan
}

\begin{abstract}
Abstrak
Salah satu penyebab infeksi adalah bakteri Staphylococcus aureus. Antibakteri telah memberikan kontribusi yang efektif terhadap kontrol infeksi Staphylococcus aureus. Salah satu tanaman tradisional yang dianggap memiliki khasiat antibakteri adalah daun sirsak (Annona muricata L.). Tujuan dari penelitian ini untuk mengetahui efektivitas rebusan daun sirsak (Annona muricata L.) sebagai antibakteri terhadap bakteri Staphylococcus aureus. Bakteri adalah sel prokariotik dan uniselular. Bakteri Staphylococcus aureus merupakan salah satu bakteri gram positif dan dapat menyebabkan penyakit diare,nyeri otot, dan penyakit kulit seperti jerawat, borok dan bisul. Penelitian dilakukan dengan metode eksperimental secara uji mikrobiologi dengan pengambilan sampel secara purposive sampling. Sampel penelitian adalah daun sirsak (Annona muricata L.) yang diambil dari daerah Perumnas Mandala - Medan. Uji aktivitas antibakteri dilakukan menggunakan metode difusi yaitu menggunakan media agar yang telah ditanami bakteri, kemudian dibuat 5 hole. Empat hole ditetesi larutan uji yaitu rebusan daun sirsak 10\%, 20\%, 30\%, 40\% dan satu hole ditetesi kontrol negatif yaitu aquadest. Menurut Farmakope Indonesia Edisi IV, zona hambatan antibakteri yang memuaskan adalah 14-16 mm. Dari data hasil pengamatan dapat dilihat bahwa rebusan daun sirsak $10 \%$ dan $20 \%$ belum dapat dikatakan sebagai antibakteri, tetapi sudah dapat menghambat pertumbuhan bakteri. Rebusan daun sirsak 30\% dan $40 \%$ telah dapat dikatakan sebagai antibakteri dengan masing-masing diameter zona hambatnya $14,8 \mathrm{~mm}$ dan $18,5 \mathrm{~mm}$. Kontrol negatif yaitu aquadest ternyata tidak memiliki efek antibakteri.
\end{abstract}

Kata Kunci : Staphylococcus aureus, Antibakteri, Daun Sirsak, Rebusan

\section{Latar Belakang}

Banyak sekali tanaman yang dapat dimanfaatkan sebagai obat tradisional, diantaranya daun sirsak (Annona muricata L.). Tanaman sirsak banyak digunakan sebagai tanaman obat, karena tanaman ini memiliki khasiat obat dan digunakan dalam penyembuhan maupun pencegahan penyakit.

Penggunaan sirsak sebagai obat-obatan sebenarnya bukan merupakan suatu hal yang baru di Indonesia. Secara turun temurun, sirsak telah digunakan oleh sebagian masyarakat Indonesia untuk mengobati beberapa penyakit. Bagi etnis Sunda daun sirsak digunakan untuk menghilangkan mual, bisul, dan rematik. Etnis Kutai memilih daun sirsak untuk mengobati diare. Namun kini penelitian menemukan daun sirsak mampu membunuh sel kanker, bahkan daun sirsak ini lebih ampuh dibandingkan kemoterapi dalam pengobatan kanker (Wicaksono, 2012). Daun sirsak ini juga digunakan untuk mencegah dan mengobati abses, sebagai obat diabetes, mengatasi demam, mengobati borok, bisul, kurap, sebagai obat penenang, mengatasi jantung berdebar dan gangguan saluran kencing (Wicaksono, 2012). Selain itu daun sirsak juga dapat menghambat pertumbuhan bakteri. (Trubus Vol.10).

Bakteri merupakan mikroorganisme bersel tunggal yang mempunyai bentuk dan susunan sel sederhana, umumnya bersifat pathogen yaitu dapat menghasilkan toksin berupa enterotoksin yang dapat mencemari makanan dan apabila dikonsumsi manusia akan menimbulkan penyakit. Salah satu bakteri tersebut adalah Staphylococcus aureus (Pratiwi, 2008). Bakteri Staphilococcus aureus merupakan bakteri gram positif, bersifat hidup secara aerob fakultatif, tidak mempunyai flagel dan spora.

Permasalahan dalam penelitian ini apakah ada efek antibakteri rebusan daun sirsak (Annona muricata $L$ ) terhadap pertumbuhan bakteri Staphylococcus aureus. Adapun tujuan penelitian ini adalah untuk mengetahui pada konsentrasi rebusan daun sirsak (Annona muricata L.) efektif menghambat pertumbuhan bakteri Staphylococcus aureus.

Jenis Penelitian yang digunakan dalam penelitian ini adalah penelitian eksperimental secara uji mikrobiologi, dimana dilakukan pada 2 kelompok yaitu: kelompok 1 : Kelompok bakteri Staphylococcus aureus yang diberikan rebusan daun sirsak dengan konsentrasi yang berbeda dan Kelompok 2 :Bakteri Staphylococcus aureus yang diberikan aquadest. Penelitian ini dilakukan di Laboratorium Mikrobiologi Jurusan Farmasi Poltekkes Kemenkes Medan, Jln. Air langga No. 20 Medan. Penelitian dilakukan selama 2 minggu.

Populasi pada penelitian ini adalah daun sirsak yang diambil dari daerah Perumnas Mandala Medan. Sampel pada penelitian ini adalah daun sirsak muda, daun yang diambil adalah daun ketiga sampai kelima dari ujung. 
Daun sirsak dibersihkan dari pengotoran, dicuci dengan air bersih mengalir lalu ditiriskan. Iris daun sirsak dengan lebar 0,3 cm (3 mm). Keringkan pada suhu kamar, terlindung dari sinar matahari langsung kemudian daun yang sudah kering disimpan di dalam wadah plastik

Alat yang digunakan autoklaf, batang pengaduk, cawan petri, erlenmeyer $100 \mathrm{ml}$, erlenmeyer $75 \mathrm{ml}$, gelas ukur, incubator, jangka sorong, kain flannel, kapas, kawat ose, kertas perkamen, labu tentukur, lampu spiritus, mikroskop, neraca analitik, oven, panci penangas, air pencetak lubang, pipet volume $1 \mathrm{ml}$, rak tabung reaksi, spidol, tabung reaksi, tali atau benang dan thermometer. Bahan yang digunakan daun sirsak (Annona muricata L.), aquadest, Media Muller Hinton Agar (MHA), Media Manotol Salt Agar (MSA), Nutrient Agar (NA),larutan $\mathrm{NaCl}$ 0,9\%, larutan Fuchin, larutan Kristal Violet, larutan Lugol, Suspensi Mc. Farland

Pembuatan rebusan daun sirsak adalah Konsentrasi rebusan daun sirsak (Annona muricata L.) yang akan dibuat adalah 10\%, 20\%, 30\%, 40\%.

Untuk rebusan daun sirsak $40 \%$ adalah 40 gram daun sirsak yang kering, kemudian dimasukkan ke dalam panci dan diberi aquadest sebanyak $100 \mathrm{ml}$, panaskan di atas penangas air sampai suhu $90^{\circ} \mathrm{C}$ selama 30 menit sambil sesekali diaduk, kemudian serkai dengan menggunakan kain flannel, tambahkan air panas secukupnya melalui ampas hingga diperoleh volume rebusan $100 \mathrm{ml}$. a. Untuk membuat $5 \mathrm{ml}$ rebusan daun sirsak 30\%, dibuat dengan cara pengenceran dari rebusan daun sirsak $40 \%$ yaitu:

$$
\begin{array}{cc}
\mathrm{V}_{1} \cdot \mathrm{C}_{1}=\mathrm{V}_{2} \cdot \mathrm{C}_{2} \\
\mathrm{~V}_{1} \cdot 40 \% & =5.30 \% \\
\mathrm{~V}_{1}=3,75 \mathrm{ml}
\end{array}
$$

Maka pipet 3,75 ml rebusan daun sirsak 40\%, tambahkan aquadest sampai $5 \mathrm{ml}$

b. Cara yang sama dengan rebusan daun sisrak 30\%, maka untuk membuat $5 \mathrm{ml}$ rebusan daun sirsak 20\%, diambil sebanyak $2.5 \mathrm{ml}$. Maka pipet 2,5 ml rebusan daun sirsak 40\%, tambahkan aquadest sampai $5 \mathrm{ml}$

c. Untuk membuat $5 \mathrm{ml}$ rebusan daun sirsak $10 \%$ diambil $1.25 \mathrm{ml}$.

Maka pipet 1,25 ml rebusan daun sirsak 40\%, tambahkan aquadest sampai $5 \mathrm{ml}$

Prosedur Kerja 1. Media Manitol Salt Agar (MSA) adalah: jumlah media yang harus dilarutkan dalam 1 liter aquadest pada etiket adalah $111 \mathrm{~g} / \mathrm{L}$. Banyaknya MSA yang diperlukan untuk $50 \mathrm{ml}$ adalah :

$$
\frac{50 \mathrm{ml}}{1000 \mathrm{ml}} \times 111 \mathrm{~g}=5,55 \mathrm{~g}
$$

Pembuatan :

1. Timbang MSA sebanyak 5,55 g

2. Masukkan kedalam erlenmeyer, larutkan dengan aquadest sebanyak $50 \mathrm{ml}$

3. Panaskan sampai mendidih

4. Angkat dan tutup Erlenmeyer dengan kapas, lapisi dengan kertas perkamen, kemudian ikat dengan benang

5. Sterilkan dengan autoklaf pada suhu $121^{\circ} \mathrm{C}$ selama 15 menit
6. Setelah steril, angkat dari autoklaf dengan perlahan-lahan dan hati-hati.

7. Dinginkan, lalu buka kertas perkamen yang diikatkan pada Erlenmeyer kemudian tuang kedalam cawan petri secara aseptis.

\section{Media Nutrien Agar (NA)}

Jumlah media yang harus dilarutkan dalam 1 liter aquadest pada etiket adalah $20 \mathrm{~g} / \mathrm{L}$. Banyaknya Nutrien Agar yang dibutuhkan untuk $20 \mathrm{ml}$ adalah:

$$
\frac{20 \mathrm{ml}}{1000 \mathrm{ml}} \times 20 \mathrm{~g}=0,4 \mathrm{~g}
$$

Pembuatan:

1. Timbang Nutrien Agar sebanyak 0,4 g

2. Masukkan kedalam erlenmeyer, larutkan dengan aquades sebanyak $20 \mathrm{ml}$

3. Panaskan sampai mendidih

4. Angkat, lalu bagi dalam beberapa tabung (sesuai kebutuhan), tutup dengan kapas, lapisi dengan kertas perkamen kemudian ikat dengan benang.

5. Sterilkan dalam autoklaf pada suhu $121^{\circ} \mathrm{C}$ selam 15 menit. Setelah steril, angkat dari autoklaf dengan perlahan-lahan dan hati-hati.

6. Dinginkan, buka kertas perkamen yang diikatkan pada tabung kemudian miringkan tabung yang berisi Nutrien Agar untuk memperoleh agar miring.

7. Biarkan sampai membeku, setelah itu lakukan penanaman bakteri dengan menggoreskan bakteri secara zig-zag pada media.

\section{Media Mueller Hilton Agar (MHA)}

Jumlah media yang harus dilarutkan dalam 1 liter aquadest pada etiket adalah $34 \mathrm{~g} / \mathrm{L}$. Banyaknya MHA yang diperlukan untuk $100 \mathrm{ml}$ adalah:

$$
\begin{aligned}
& \frac{100 \mathrm{ml}}{1000 \mathrm{ml}} \text { } \text { P } 34 \text { gram = 3,4 gram } \\
& \text { Pembuatan } \\
& \text { 1. Timbang MHA sebanya 3,4 gram } \\
& \text { 2. Masukkan kedalam erlenmeyer, larutkan } \\
& \text { dengan aquadest sebanyak } 100 \mathrm{ml} \\
& \text { 3. Panaskan sampai mendidih } \\
& \text { 4. Angkat dan tutup erlenmeyer dengan kapas, } \\
& \text { lapisi dengan kertas perkamen kemudian ikat } \\
& \text { dengan benang. } \\
& \text { 5. Sterilkan dalam autoklaf pada suhu } 121^{0} \mathrm{C} \\
& \text { selama } 15 \text { menit. }
\end{aligned}
$$

\section{Larutan NaCl 0,9\%}

Pembuatan:

$\mathrm{NaCl}$ ditimbang sebanyak 0,9 g lalu dilarutkan dengan aquadest hingga $100 \mathrm{ml}$ dalam labu tentukur, kemudian disterilkan dalam autoclave pada suhu $121^{\circ} \mathrm{C}$ selama 15 menit. 


\section{Suspensi Standar Mc. Farland}

Pembuatan:

Campurkan Larutan Asam Sulfat dan Larutan Barium KLorida kedalam tabung reaksi dan dikocok homogen. Apabila kekeruhan suspensi bakteri uji sama dengan kekeruhan suspense standar Mc. Farland, maka konsentrasi suspensi bakteri adalah $10^{8} \mathrm{koloni} / \mathrm{ml}$.

\section{Pembiakan Bakteri}

1. Ambil satu ose dari suspensi bakteri Staphylococcus aureus

2. Kemudian tanam ke media MSA dengan cara menggoreskan

3. Inkubasi dalam inkubator pada suhu $37^{\circ} \mathrm{C}$ selama 18 - 24 jam

4. Amati pertumbuhan koloni pada media

5. Hasil yang diperoleh adalah koloni berwarna kuning keemasan, menunjukkan Staphylococcus aureus (+), lalu lakukan pengecatan gram dengan cara:

a. Ambil biakan bakteri yang telah berumur 18 24 jam, letakkan pada kaca objek yang telah diberikan aquadest lebih dahulu, lalu fiksasi

b. Tambahkan kristal violet, diamkan 1 - 2 menit, kemudian bilas dengan aquadest dan tambahkan larutan lugol, biarkan selama 1 menit

c. Setelah 1 menit lugol dibilas dengan alkohol 95\%, diamkan selama 5-15 detik, bilas dengan aquadest

d. Tambahkan larutan Fuchsin diamkan kira-kira 20 detik, bilas dengan aquadest lalu keringkan, amati hasilnya di bawah mikroskop dengan perbesaran 10 x 40 dan 10 x 100. Jika bakteri tersebut adalah Staphylococcus aureus hasil pengecatan gram yang diperoleh dibawah mikroskop adalah bakteri berwarna ungu yang merupakan bakteri gram positif membentuk gerombol seperti buah anggur.

6. Koloni spesifik Staphylococcus aureus diambil satu ose lalu ditanamkan pada Nutrien Agar miring, inkubasi dalam inkubator pada suhu $37^{0} \mathrm{C}$ selama 18 - 24 jam

\section{Pengenceraan Bakteri Staphyloccocus aureus}

1. Masukkan kurang lebih 1 ml larutan $\mathrm{NaCl}$ 0,9\% kedalam tabung kosong, kemudian ambil satu ose biakan bakteri Staphylococcus aureus yang berumur 18 - 24 jam yaitu biakan yang berasal dari Nutrien Agar

2. Tambahkan terus larutan $\mathrm{NaCl} 0,9 \%$ sampai diperoleh suspensi dengan kekeruhan yang sama dengan suspensi standar Mc. Farland, maka konsentrasi suspensi bakteri adalah $10^{8}$ koloni/ml.

3. Pipet sebanyak 0,1 ml suspensi bakteri kedalam tabung reaksi kemudian tambahkan 9,9 ml larutan $\mathrm{NaCl}$ 0,9\%, maka konsentrasi suspensi bakteri adalah $10^{6} \mathrm{koloni} / \mathrm{ml}$.
Uji Efektivitas Rebusan Daun Sirsak Terhadap Pertumbuhan Bakteri Staphylococcus aureus

1. Sterilkan semua alat dan bahan yang akan digunakan.

2. Buat persediaan inokulum.

3. Pipet $0,1 \mathrm{ml}$ suspensi bakteri dengan konsentrasi $10^{6} \mathrm{koloni} / \mathrm{ml}$ ke dalam $100 \mathrm{ml}$ media MHA dengan suhu $45^{\circ} \mathrm{C}-50^{\circ} \mathrm{C}$ lalu kocok sampai homogen, kemudian tuang segera sebanyak $15 \mathrm{ml}$ kedalam cawan petri steril, lalu biarkan memadat.

4. Buat 5 hole, 4 hole untuk rebusan daun sirsak,1 hole untuk aquadest sebagai kontrol negatif.

5. Tetesi ke dalam hole $0,1 \mathrm{ml}$ rebusan daun sirsak yang telah dibuat dengan konsentrasi 10\%, 20\%, $30 \%, 40 \%$.

6. Inkubasikan selama 24 jam pada suhu $37^{\circ} \mathrm{C}$.

7. Baca hasilnya dengan mengukur zona hambatan berupa daerah yang tampak jernih yang tidak ditumbuhi oleh bakteri Staphylococcus aureus.

8. Diukur dalam satuan mm.

Percobaan dilakukan triplo yaitu dilakukan sebanyak 3 kali untuk masing-masing rebusan daun sirsak.

\section{Hasil}

Pengukuran hasil penelitian dilakukan dengan mengukur zona hambatan rebusan daun sirsak (Annona muricata $L$ ) yang dibuat dengan konsentrasi $10 \%, 20 \%$, $30 \%$ dan $40 \%$ terhadap pertumbuhan bakteri Staphylococcus aureus dimana terlihat daerah jernih disekitar lubang difusi (hole), seperti yang terlihat pada tabel berikut

Tabel 4.1.1. Hasil pengamatan zona hambat rebusan daun sirsak

\begin{tabular}{|l|l|l|l|l|l|}
\hline $\begin{array}{l}\text { Konsentrasi } \\
\text { Rebusan } \\
\text { Daun Sirsak }\end{array}$ & \multicolumn{2}{|l|}{ Cawan Petri } & $\begin{array}{l}\text { Rata-rata } \\
\text { Zona } \\
\text { Hambatan } \\
\text { (mm) }\end{array}$ & $\begin{array}{l}\text { Zona } \\
\text { Hambatan } \\
\text { sebagai } \\
\text { Antibakteri } \\
\text { Menurut } \\
\text { FI Ed. IV } \\
\text { Hal 896 } \\
\text { (mm) }\end{array}$ \\
\hline $10 \%$ & 11,5 & 11,4 & 12,1 & 11,6 & \\
\hline $20 \%$ & 12,8 & 13,5 & 12,6 & 12,9 & \\
\hline $30 \%$ & 14,6 & 14,4 & 15,5 & 14,8 & \multirow{2}{*}{$14-16$} \\
\hline $40 \%$ & 17,3 & 19,4 & 18,9 & 18,5 & \\
\hline Aquadest & 0 & 0 & 0 & 0 & \\
\hline & & & & & \\
\hline
\end{tabular}

\section{Pembahasan}

Pada konsentrasi $10 \%$ rata-rata zona hambatan $11,6 \mathrm{~mm}, 20 \%$ rata-rata zona hambatan $12,9 \mathrm{~mm}, 30 \%$ rata-rata zona hambatan $14,8 \mathrm{~mm}$ dan $40 \%$ rata-rata zona hambatan $18,5 \mathrm{~mm}$.

Dari hasil pengukuran zona hambat pertumbuhan bakteri Staphylococcus aureus dengan pemberian rebusan daun sirsak diatas, konsentrasi rebusan daun sirsak 30\% 
sudah dapat dikatakan sebagai antibakteri, karena menurut Farmakope Indonesia Edisi IV hal. 896 bahwa rata-rata zona hambat yang dapat dikatakan sebagai antibakteri adalah $14-16 \mathrm{~mm}$.

Pada kontrol negatif yaitu aquadest tidak memberikan efek antibakteri apapun. Pada konsentrasi 40\% memberikan efek antibakteri yang memiliki zona hambat lebih luas daripada konsentrasi 30\%. Hal ini dikarenakan pada konsentrasi 40\% memiliki rebusan daun sirsak yang lebih banyak daripada konsentrasi 30\%.

\section{SIMPULAN DAN SARAN}

\section{Simpulan}

Berdasarkan hasil penelitian yang diperoleh dari rebusan daun sirsak terhadap pertumbuhan bakteri Staphylococcus aureus dapat disimpulkan bahwa tiap konsentrasi memberikan luas daerah hambat yang berbeda.

1. Pada konsentrasi $10 \%$ dan $20 \%$ rebusan daun sirsak sudah terlihat adanya zona hambatan tetapi belum dapat dikatakan sebagai antibakteri.

2. Pada konsentrasi $30 \%$ sudah bersifat sebagai antibakteri dengan diameter zona hambatan 14,8 mm karena menurut Farmakope Indonesia Edisi IV, bahwa rata-rata zona hambatan yang dapat dikatakan sebagai antibakteri adalah lebih kurang $14-16 \mathrm{~mm}$.

3. Pada konsentrasi $40 \%$ bersifat sebagai antibakteri dengan diameter zona hambat yang lebih luas yaitu sebesar 18,5 mm.

4. Semakin besar konsentrasi rebusan daun sirsak yang digunakan, maka semakin luas zona hambatan antibakteri.

\section{Saran}

1. Disarankan kepada peneliti selanjutnya untuk meneliti khasiat lain dari daun sirsak (Annona muricata L.)

2. Disarankan kepada peneliti selanjutnya untuk meneliti efek antibakteri rebusan daun sirsak
(Annona muricata L.) pada jenis bakteri lain seperti : Escherichia coli dan Salmonella.

3. Disarankan kepada peneliti selanjutnya untuk meneliti efek antibakteri daun sirsak dalam bentuk sediaan lain

\section{DAFTAR PUSTAKA}

Departemen Kesehatan RI. 1979. Farmakope Indonesia Edisi Ketiga. Jakarta

Hariana, A. 2007. Tumbuhan Obat dan Khasiatnya Edisi Ketiga. Jakarta: Penebar Swadaya

Jawetz, E., Menick, J.L., dan Adelberg, E.A. 2001. Mikrobiologi Kedokteran Edisi 23. Jakarta: Penerbit EGC

Jhonhref. 2007. Tanaman Obat Asli Milik Masyarakat Bangsa dan Negara.

Joe, W. 2012. Dahsyatnya Khasiat Sirsak. Yogyakarta: Penerbit Andi.

Pelczar, M.J, Jr. dan Chan, E.C.S. 1988. Dasar-Dasar Mikrobiologi Jilid 2. Penerjemah: Hadioetomo, R.S, dkk. Jakarta: Penerbit Universitas Indonesia

Pratiwi, S.T. 2008. Mikrobiologi Farmasi. Jakarta: Penerbit Erlangga

S.Warisno. 2012. Daun Sirsak Langkah Alternatif Menggempur Penyaki. Jakarta: PT. Gramedia Pustaka Utama

Staf Pengajar Kedokteran Universitas Indonesia. 1993. Mikrobiologi Kedokteran. Jakarta: Binarupa Aksara

Syamsuhidayat, S.S \& Johnny, R.H. 1991. Inventaris Tanaman Obat.

Departemen Kesehatan RI Badan Penelitian dan Pengembangan Kesehatan

Trubus volume 10. 2012. Herbal Indonesia Berkhasiat: Bukti Ilmiah \& Cara Racik Edisi Revisi. Depok: PT Trubus Swadaya

Voight, R. 1994. Buku Pelajaran Teknologi Farmasi. Yogyakarta: Gadjah Mada University Press

Wicaksono, A. 2012. Kalahkan Kanker dengan Sirsak. Jakarta: Citra Media Mandiri 